\title{
Cukorbetegség és retinopathia diabetica regionális egyenlőtlenségei Magyarországon az 50 éves és idősebb korú lakosság körében
}

\author{
Tóth Gábor dr. ${ }^{1}$ - Szabó Dorottya dr. ${ }^{1}$ - Sándor Gábor László dr. ${ }^{1}$ \\ Pék Anita dr. ${ }^{1,2}$. Szalai Irén dr. ${ }^{1}$ - Lukács Regina dr. ${ }^{1,3}$ \\ Tóth Georgina Zsófia dr. ${ }^{1}$ - Papp András dr. ${ }^{1}$. Nagy Zoltán Zsolt dr. ${ }^{1}$ \\ Hans Limburg dr. ${ }^{4}$ - Németh János dr. ${ }^{1}$ \\ 'Semmelweis Egyetem, Általános Orvostudományi Kar, Szemészeti Klinika, Budapest \\ ${ }^{2}$ Petz Aladár Megyei Oktató Kórház, Szemészeti Osztály, Győr \\ ${ }^{3}$ Pest Megyei Flór Ferenc Kórház, Szemészeti Osztály, Kistarcsa \\ ${ }^{4}$ Health Information Services, Grootebroek, Hollandia
}

\begin{abstract}
Bevezetés: A cukorbetegség az egyik leggyakoribb oka a vakságnak az 50 éves vagy idősebb korú lakosság körében. Célkitüzés: Tanulmányunk célja a cukorbetegség és a retinopathia diabetica (RD) prevalenciájának meghatározása, illetve a cukorbetegek szemészeti ellátása lefedettségének vizsgálata hazánk különböző részein. Módszer: Százöt lakókörzetben, összesen 3675,50 éves vagy idősebb korú személyt vontunk be a vizsgálatba. A standardizált rapid assessment of avoidable blindness (RAAB) + diabetic retinopathy module (DRM) segítségével vizsgáltuk a résztvevőket, majd a Nyugat-, Közép- és Kelet-Magyarország közötti különbségeket. Eredmények: A cukorbetegség prevalenciája Kelet-Magyarországon (20,9\%) magasabb volt, mint Nyugat- (19,5\%) és Közép-Magyarországon (19,5\%). Az RD prevalenciája Nyugat-Magyarországon $(24,1 \%)$ magasabb volt, mint Közép- $(17,8 \%)$ és Kelet-Magyarországon (19,6\%). A közép-magyarországi résztvevők között volt a legkisebb azon páciensek aránya (19,1\%), akik még sohasem vettek részt szemfenékvizsgálaton. Következtetések: A cukorbetegség szemészeti szövődményei gyakoriságának csökkentése céljából fontos lenne a szemészeti alapellátás - föleg vidéki településeken való - megerősítése, vagy szemészeti telemedicinális országos szürés bevezetése és végzése. Orv. Hetil., 2017, 158(10), 362-367.
\end{abstract}

Kulcsszavak: cukorbetegség, retinopathia diabetica, prevalencia, regionális egyenlőtlenség

Regional disparities in the prevalence of diabetes and diabetic retinopathy in Hungary in people aged 50 years and older

\begin{abstract}
Introduction: Diabetes mellitus (DM) is one of the main causes of blindness among persons aged 50 years and older. Aim: The purpose of our survey was to estimate the prevalence of DM and diabetic retinopathy (DR), as well as to assess the coverage of diabetic eye care services in different regions of Hungary. Method: In 105 clusters, 3675 people aged 50 years and older were included in the survey. The standardized rapid assessment of avoidable blindness (RAAB) with the diabetic retinopathy module (DRM) was used to examine the participants. Thereafter, differences between West-, Middle- and East-Hungary were analysed. Results: Prevalence of DM was higher in East-Hungary $(20.9 \%)$, than in West- $(19.5 \%)$ and in Middle-Hungary $(19.5 \%)$. Prevalence od DR was higher in West-Hungary (24.1\%), than in Middle- (17.8\%) and in East-Hungary (19.6\%). Proportion of participants who never had a fundus examination for DR was the lowest in Middle-Hungary (19.1\%). Conclusions: Primary care should be strenghten mainly in country settlements or telemedical eye screening program should be started to decrease the prevalence of diabetic eye complications.
\end{abstract}

Keywords: diabetes mellitus, diabetic retinopathy, prevalence, regional disparity 
Tóth, G., Szabó, D., Sándor, G. L., Pék, A., Szalai, I., Lukács, R., Tóth, G. Zs., Papp, A., Nagy, Z. Zs., Limburg, H., Németh, $J$. [Regional disparities in the prevalence of diabetes and diabetic retinopathy in Hungary in people aged 50 years and older]. Orv. Hetil., 2017, 158(10), 362-367.

(Beérkezett: 2016. december 15.; elfogadva: 2017. január 3.)

\section{Rövidítések}

$\mathrm{RAAB}+\mathrm{DRM}=$ rapid assessment of avoidable blindness + diabetic retinopathy module; $\mathrm{RD}=$ retinopathia diabetica

A cukorbetegség (1-es és 2-es típusú diabetes mellitus) globális népegészségügyi probléma, prevalenciája gyorsan nő világszerte. 2015 -ben 415 millióra becsülték a cukorbetegek számát a világban, de a növekedés üteme alapján 2040-re számuk elérheti a 642 millió fót [1]. Európában 59 millióra becsülik a cukorbetegséggel élők számát, ami 9,1\%-os prevalenciának felel meg, de 2050re a cukorbetegség előfordulási gyakorisága elérheti a $10,7 \%$-ot is [1].

A retinopathia diabetica (RD) a cukorbetegség fontos szövődménye, amelynek hatására kóros elváltozások alakulnak ki a látóhártya kisereiben. A világban majd minden harmadik cukorbetegnek van valamilyen fokú RD-je [2]. Az RD globálisan a vakság 1,0-4,8\%-áért felelős [3, 4]. A cukorbetegség és az RD kapcsán is egyaránt fontos a friss epidemiológiai adatok szerzése, hiszen világszerte az egészségügyi összkiadások körülbelül 12-25\%-a a cukorbetegség és szövődményeinek kezelésére fordítódik $[1,5]$.

Szürőprogramok segítségével, a cukorbetegség rendszeres kontrolljával és az RD kezelésével a cukorbetegség következtében kialakuló látásromlás és vakság az esetek többségében megelőzhető lenne [2]. A VISION 2020: the Right to Sight és a WHO: Global Action Plan 20142019 világméretü kezdeményezések, amelyek az elkerülhető vakság eliminálását tüzték ki célul 2020-ig [6, 7]. Első lépésként ezen cél eléréséhez epidemiológiai adatok nyerése szükséges a cukorbetegség és az RD előfordulási gyakoriságára vonatkozólag.

A rapid assessment of avoidable blindness (RAAB) + diabetic retinopathy module (DRM) gyors és hatékony metodika populációalapú vizsgálatok végzésére, a cukorbetegség és az RD prevalenciájának felmérésére egy meghatározott földrajzi területen, az 50 éves és idősebb korú lakosság körében [8]. A RAAB + DRM metodika megbízhatósága és validitása ismert $[9,10]$.

Az utóbbi időben több tanulmány is megjelent a cukorbetegség és az RD hazai országos előfordulási gyakoriságával kapcsolatban, azonban regionális prevalenciájuk ismeretlen $[11,12]$. A cukorbetegség és az RD prevalenciája regionális megoszlásának, illetve a szemészeti ellátás regionális lefedettségének ismerete szükséges az alapellátás minőségének és a szemészeti rendelések elérhetőségének megítéléséhez.
Jelen cikkünkben ismertetendő altanulmányunk célja a cukorbetegség és az RD regionális előfordulási gyakoriságának becslése az 50 éves és idősebb korú hazai lakosság körében, illetve a szemészeti vizsgálatok regionális lefedettségének vizsgálata a RAAB + DRM metodika segítségével.

\section{Módszer}

A RAAB + DRM felmérést a Semmelweis Egyetem Szemészeti Klinikájának szervezésében végeztük 2015 áprilisa és júliusa között [11]. A terepmunka megkezdése előtt a részt vevő orvosok, nővérek és asszisztensek ötnapos tréningen vettek részt, ahol a szemészeti vizsgálat protokolljáról, a vércukormérések módjáról, illetve az indirekt binokuláris szemtükör és a RAAB szoftver használatáról kaptak naprakész információkat.

\section{Mintavétel}

A tervezett vizsgálati populáció 105 lakókörzetből és 3675 személyből állt. Minden lakókörzetben 35 fó 50 éves vagy idősebb korú személyt vizsgáltunk meg. A vizsgálati populáció nagyságát a vakság az 50 éves és idősebb korú lakosság körében 2,5\%-ra becsült prevalenciájának alapján határoztuk meg a RAAB v6 szoftver segítségével. A Központi Statisztika Hivatal (KSH) az egész ország területéról randomizált módon, a RAAB-algoritmus segítségével 105 lakókörzetet választott ki a 2011 es szavazókörzetek listájáról, hogy a minta országosan megfelelően reprezentatív legyen. A felmérésben részt vevő csapatok házról házra jártak minden kijelölt lakókörzetben, amíg 35 fö 50 éves vagy idősebb korú lakost nem vizsgáltak meg a RAAB + DRM protokollnak megfelelően.

\section{Cukorbetegség és retinopathia diabetica}

Minden résztvevő esetében ujjbegyből vérmintát vettünk, majd pedig digitális vércukormérővel megmértük a résztvevők vércukorszintjét. Cukorbetegnek tekintettünk minden résztvevőt, akinél már korábbról ismert volt a cukorbetegség diagnózisa, aki cukorbetegség kezelésére gyógyszert használt vagy akinek az aktuális vércukorszintje $11,1 \mathrm{mmol} / 1$ vagy magasabb volt.

A cukorbeteg résztvevőktől megkérdeztük az utolsó pupillatágításban végzett szemfenékvizsgálat időpontját. Minden beleegyező cukorbetegnél a pupilla tágítását kö- 
vetően indirekt binokuláris szemtükör segítségével szemfenékvizsgálatot végeztünk az RD stádiumának és gyakoriságának meghatározása céljából.

A prevalenciák regionális vizsgálatához három országrészt jelöltünk ki: Nyugat-, Közép- és Kelet-Magyarországot. Nyugat- és Kelet-Magyarország határát a Duna folyó vonalában jelöltük meg. Közép-Magyarországhoz tartozott Pest megye és Budapest közigazgatási területe.

\section{Statisztikai analizis}

A RAAB v6 és a Statistica 11.0 (StatSoft Inc., Tulsa, OK, Amerikai Egyesült Államok) szoftver segítségével végeztük el a statisztikai analízist. Kruskal-Wallis-tesztet használtunk az életkori adatok és $\chi^{2}$-próbát a prevalenciaadatok részletesebb elemzéséhez. A p-értéket statisztikailag szignifikánsnak tekintettük, amennyiben $<0,05$ volt.

\section{Etikai engedély}

A Semmelweis Egyetem Regionális, Intézményi Tudományos és Kutatásetikai Bizottság (Budapest) engedélyezte a tanulmányt. A tanulmány összhangban van a Helsinki Deklaráció elveivel. Minden résztvevőtől írásos beleegyező nyilatkozatot kaptunk.

Amennyiben a vizsgált résztvevők esetében további vizsgálatot vagy kezelést tartottunk szükségesnek, a pácienst háziorvosához vagy szemészeti szakrendelésre irányítottuk.

\section{Eredmények}

Összesen 3675 fö 50 éves vagy idősebb korú lakost vontunk be a RAAB + DRM felmérésbe, akik közül 3523 föt $(95,9 \%)$ vizsgáltunk meg (1. táblázat).

A cukorbetegség prevalenciája (2. táblázat) magasabb volt Kelet-Magyarországon, mint Nyugat- és KözépMagyarországon, a különbség nem volt szignifikáns. Nem volt szignifikáns különbség Nyugat-, Közép- és Kelet-Magyarország között sem a cukorbetegek életkorában (69 év [61-75], 50-93 [medián, interkvartilis tartomány, tartomány] vs. 69 év [62-75], 50-96 vs. 70 év [63-76], 50-92), sem pedig az ismert cukorbetegek körében a cukorbetegség átlagos fennállási idejében (9 év [3-15], 0-93 vs. 10 év [5-20], 20-80 vs. 10 év [5-18], 0-84).

Közép-Magyarországon gyakrabban mértünk 11,1 $\mathrm{mmol} / \mathrm{l}$ alatti vércukorszintet az ismert cukorbetegek körében, mint Kelet- és Nyugat-Magyarországon (3. táblázat), azonban a különbség itt sem volt szignifikáns. A korábban fel nem ismert cukorbetegek előfordulási gyakorisága Közép- és Kelet-Magyarországon több mint másfélszeres volt a Nyugat-Magyarországon találthoz képest, azonban ez a különbség sem volt szignifikáns.

$\mathrm{Az}$ RD prevalenciája (4. táblázat) Nyugat-Magyarországon volt a legmagasabb, majd Kelet-Magyarorszá-
1. táblázat $\mid$ A felmérésben részt vevők száma és százalékos megoszlása a különböző országrészekben

\begin{tabular}{lcc|cc|cc}
\hline & \multicolumn{2}{c|}{$\begin{array}{c}\text { Nyugat- } \\
\text { Magyarország }\end{array}$} & \multicolumn{2}{c|}{$\begin{array}{c}\text { Közép- } \\
\text { Magyarország }\end{array}$} & \multicolumn{2}{c}{$\begin{array}{c}\text { Kelet- } \\
\text { Magyarország }\end{array}$} \\
\cline { 2 - 7 } & $\mathrm{n}$ & $\begin{array}{c}\text { Meg- } \\
\text { oszlás }\end{array}$ & $\mathrm{n}$ & $\begin{array}{c}\text { Meg- } \\
\text { oszlás }\end{array}$ & $\mathrm{n}$ & $\begin{array}{c}\text { Meg- } \\
\text { oszlás }\end{array}$ \\
\hline $\begin{array}{l}\text { Vizsgált } \\
\text { lakókörzetek } \\
\text { száma }\end{array}$ & 38 & $36,2 \%$ & 29 & $27,6 \%$ & 38 & $36,2 \%$ \\
$\begin{array}{l}\text { Összes } \\
\text { résztvevố }\end{array}$ & 1330 & $36,2 \%$ & 1015 & $27,6 \%$ & 1330 & $36,2 \%$ \\
$\begin{array}{l}\text { Vizsgált } \\
\text { résztevô }\end{array}$ & 1278 & $36,3 \%$ & 951 & $27,0 \%$ & 1294 & $36,7 \%$ \\
\hline
\end{tabular}

2. táblázat $\mid$ Az 50 éves és idősebb korú populáció körében a cukorbetegség regionális előfordulási gyakorisága Magyarországon

\begin{tabular}{|c|c|c|c|c|c|c|}
\hline & \multicolumn{2}{|c|}{$\begin{array}{c}\text { Nyugat- } \\
\text { Magyarország }\end{array}$} & \multicolumn{2}{|c|}{$\begin{array}{c}\text { Közép- } \\
\text { Magyarország }\end{array}$} & \multicolumn{2}{|c|}{$\begin{array}{c}\text { Kelet- } \\
\text { Magyarország }\end{array}$} \\
\hline & $\mathrm{n}$ & $\%$ & $\mathrm{n}$ & $\%$ & $\mathrm{n}$ & $\%$ \\
\hline Cukorbeteg & 249 & $19,5 \%$ & 185 & $19,5 \%$ & 271 & $20,9 \%$ \\
\hline $\begin{array}{l}\text { Nem } \\
\text { cukorbeteg }\end{array}$ & 1029 & $80,5 \%$ & 766 & $80,5 \%$ & 1023 & $79,1 \%$ \\
\hline
\end{tabular}

3. táblázat

Újonnan felfedezett és már korábban diagnosztizált cukorbetegek aránya, illetve az ismert cukorbetegek aktuális vércukorszintje az 50 éves és idősebb korú lakosság körében

\begin{tabular}{lcc|cc|cc}
\hline & \multicolumn{2}{c|}{$\begin{array}{c}\text { Nyugat- } \\
\text { Magyarország }\end{array}$} & \multicolumn{2}{c|}{$\begin{array}{c}\text { Közép- } \\
\text { Magyarország }\end{array}$} & \multicolumn{2}{c}{$\begin{array}{c}\text { Kelet- } \\
\text { Magyarország }\end{array}$} \\
\cline { 2 - 7 } & $\mathrm{n}$ & $\%$ & $\mathrm{n}$ & $\%$ & $\mathrm{n}$ & $\%$ \\
\hline $\begin{array}{l}\text { Ismert } \\
\text { cukorbeteg }\end{array}$ & 238 & $95,6 \%$ & 172 & $93,0 \%$ & 251 & $92,6 \%$ \\
$\geq 11,1 \mathrm{mmol} / 1$ & 49 & $20,6 \%$ & 28 & $16,3 \%$ & 55 & $21,9 \%$ \\
$<11,1 \mathrm{mmol} / \mathrm{l}$ & 189 & $79,4 \%$ & 144 & $83,7 \%$ & 196 & $78,1 \%$ \\
Új cukorbeteg & 11 & $4,4 \%$ & 13 & $7,0 \%$ & 20 & $7,4 \%$ \\
\hline
\end{tabular}

4. táblázat | Szemfenékvizsgálaton átesett résztvevơk száma, illetve a retinopathia diabetica előfordulási gyakoriságának regionális jellemzői Magyarországon az 50 éves és idősebb korú cukorbeteg lakosság körében

\begin{tabular}{lcc|cc|cc}
\hline & \multicolumn{2}{c|}{$\begin{array}{c}\text { Nyugat- } \\
\text { Magyarország }\end{array}$} & \multicolumn{2}{c|}{$\begin{array}{c}\text { Közép- } \\
\text { Magyarország }\end{array}$} & \multicolumn{2}{c}{$\begin{array}{c}\text { Kelet- } \\
\text { Magyarország }\end{array}$} \\
\cline { 2 - 7 } & $\mathrm{n}$ & $\%$ & $\mathrm{n}$ & $\%$ & $\mathrm{n}$ & $\%$ \\
\hline $\begin{array}{l}\text { Szemfenék- } \\
\text { vizsgálatot } \\
\text { visszautasította }\end{array}$ & 39 & $15,7 \%$ & 49 & $26,5 \%$ & 56 & $20,7 \%$ \\
$\begin{array}{l}\text { Szemfenék- } \\
\text { vizsgálat }\end{array}$ & 210 & $84,3 \%$ & 136 & $73,5 \%$ & 215 & $79,3 \%$ \\
$\begin{array}{l}\text { Retinopathia } \\
\text { diabetica (RD) }\end{array}$ & 60 & $24,1 \%$ & 33 & $17,8 \%$ & 53 & $19,6 \%$ \\
$\begin{array}{l}\text { Nincs RD } \\
\text { Nincs }\end{array}$ & 150 & $60,2 \%$ & 103 & $55,6 \%$ & 162 & $59,8 \%$ \\
\hline
\end{tabular}


gon, a legalacsonyabb pedig Közép-Magyarországon, azonban a különbség nem volt szignifikáns.

A közép-magyarországi régióban szignifikánsan alacsonyabb volt az olyan cukorbeteg résztvevők aránya (1. ábra), akik még sohasem vettek részt pupillatágításos szemfenékvizsgálaton, mint Nyugat- vagy mint KeletMagyarországon (19,1\% vs. 29,0\% és 31,5\%; p = 0,01).

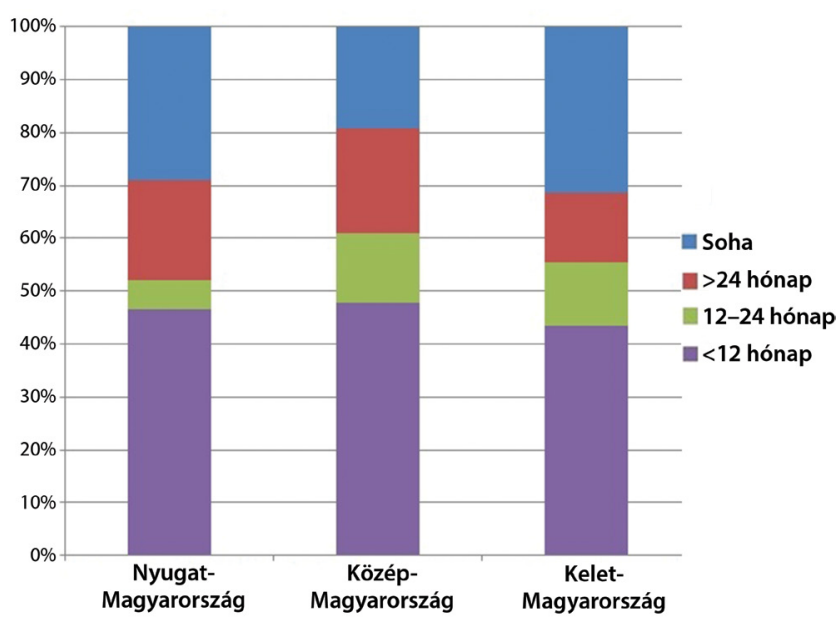

1. ábra

Utolsó szemfenékvizsgálat ideje az ismert cukorbeteg résztvevőknél

\section{Megbeszélés}

Ez a tanulmány a nemrégiben megjelent hazai RAAB + DRM felmérés [11] egyik altanulmánya, amely a cukorbetegség és az RD előfordulásának, illetve a szemészeti ellátás lefedettségének regionális egyenlőtlenségeit mutatja be. A cukorbetegség és az RD előfordulási aránya különösen fontos az 50 éves és idősebb korú lakosság körében, hiszen a vakság és a súlyos látásromlás prevalenciája ezen életkor felett a legmagasabb [13].

Felmérésünk eredményei alapján Kelet-Magyarországon magasabb a cukorbetegség előfordulási gyakorisága, mint az ország egyéb részein. Ezzel szemben az RD prevalenciája Nyugat-Magyarországon magasabb volt, mint Kelet- vagy Közép-Magyarországon. A közép-magyarországi lakosság körében pedig a legalacsonyabb volt az olyan résztvevők aránya, akik még sohasem vettek részt szemfenékvizsgálaton a cukorbetegség kapcsán.

A cukorbetegség fooként a fejlettebb országok lakosságát érinti, azok közül is leginkább az alacsony és a közepes jövedelmúeket [14]. A cukorbetegség prevalenciája a Föld felnőttkorú lakosságát figyelembe véve $8,8 \%$, Európában pedig 9,1\% [1]. Közép-európai felmérések eredményei szerint a cukorbetegség előfordulási gyakorisága a szomszédos Szlovákiában és Horvátországban 7,1\% (18 évnél idősebb korúak) [15], illetve 6,1\% (18 és 65 év közöttiek) [16] volt 2008-ban. A hazai adatok esetében Vámos 2002-ben 6,2\%-os (18 évnél idősebbek) [17], Jermendy 2010-ben 8,6\%-os [18] cukorbetegség-prevalenciát talált. Azonban a cukorbetegség előfordulási gya- korisága évről évre nő. Egy Dániában végzett felmérés szerint a cukorbetegség incidenciája évenként körülbelül 5\%-kal nő [19]. Domján nemrégiben megjelent, 1000 fós hazai mintán végzett felmérése szerint a cukorbetegség prevalenciája 2012-ben 11,7\% volt, ami a 10 évvel korábban Vámos által publikált adatokhoz (6,2\%) képest 89\%-os prevalenciaemelkedést jelent [12]. A cukorbetegség prevalenciájának folyamatos emelkedése jól ismert jelenség a fejlett ipari országok körében, leginkább az átlagéletkor és az elhízás gyakoriságának növekedésével magyarázható [20]. Nemrégiben közölt adataink szerint hazánkban, az 50 éves és idősebb korú lakosság körében a cukorbetegség prevalenciája 20,0\%, ami különösen fontos, hiszen ezen korcsoportban a cukorbetegség a vakság egyik leggyakoribb oka [11]. A cukorbetegség előfordulási gyakoriságában fellelhető regionális egyenlötlenségek fontossága abban rejlik, hogy felhívhatják a figyelmet a lakosság egészségügyi állapotában lévő regionális különbségekre és az egészségügyi ellátórendszer országrészekhez kapcsolódó esetleges hiányosságaira. Domján a nemrégiben megjelent felmérésében nyugatkelet irányú, nem szignifikáns csökkenésról számolt be a cukorbetegség-prevalenciára vonatkozólag [12]. Ezzel szemben az általunk nemrégiben publikált - nagyobb mintával (3657 fó) és teljes országos lefedettséggel végzett - felmérés adatait vizsgálva, Kelet-Magyarországon $(20,9 \%)$ nem szignifikánsan magasabb volt a cukorbetegség prevalenciája, mint Nyugat- és Közép-Magyarországon (19,5\% és 19,5\%). A két felmérés ellentétes eredményét magyarázhatja, hogy míg Domján tanulmányában csak az ismert cukorbetegek prevalenciájára vonatkozóan közöltek adatokat, addig mi a felmérésünkben vizsgáltuk a még nem diagnosztizált cukorbetegség előfordulási gyakoriságát is, ami Kelet-Magyarországon (7,4\%) több mint másfélszer magasabb volt a Nyugat-Magyarországon $(4,4 \%)$ talált értéknél. Ha vizsgálatunkban mi is csak a már korábban diagnosztizált cukorbetegek regionális megoszlását vizsgáltuk volna, akkor Domján és mtsai eredményeihez közelebb álló adatot találtunk volna a cukorbetegség prevalenciájában. Habár ez a nyugat-kelet közötti különbség nem jelentős, de jól mutatja az országrészek közötti szocioökonómiai eltéréseket. Az országrészek közötti fejlettségbeli különbségeket a regionális természeti adottságok, a gazdasági jellemzők és a munkaerő szakképzettsége befolyásolják. Hazánkban ismert az elmúlt 25 évben a közép-magyarországi régió kiugró növekedése, illetve a kelet-nyugati lejtő és egyenlőtlenség erősödése. A piacgazdaság kiépülése a fejlettebb nyugat- és közép-magyarországi országrészekre kedvezőbb hatással volt, mint a fejletlenebb, hagyományosan nehéziparral és mezőgazdasággal rendelkező kelet-magyarországi régióra [21]. Ezt a különbséget tovább erôsíti a szakképzett munkaerő fejlettebb nyugat- és közép-magyarországi területek felé való migrációja [22], illetve a jelentősebb beruházások jellemzően Nyugat- és Közép-Magyarországon való megvalósulása [23]. Mindezen társadalmi és gazdasági körülmények az egészségte- 
lenebb táplálkozáson és a mozgásszegény életmódon keresztül [24] elősegítik a cukorbetegség magasabb előfordulási gyakoriságát Kelet-Magyarországon.

Yau közleménye szerint világviszonylatban a cukorbetegek 34,6\%-ának van valamilyen fokú RD-je [2]. Hazánkban az RD prevalenciája 20,1\% az 50 éves és idősebbek körében [11]. Regionális különbségek tekintetében az RD előfordulási gyakorisága Nyugat-Magyarországon magasabb volt, mint Közép- és Nyugat-Magyarországon. Ismert, hogy a cukorbetegség fennállási idejének növekedése elősegíti az RD kialakulását [8]. NyugatMagyarországon azonban sem a születéskor várható élettartam, sem pedig az átlagéletkor nem magasabb, mint az ország egyéb részein [25]. Az $\mathrm{RD}$ némileg magasabb nyugat-magyarországi prevalenciáját magyarázó lényeges tényező lehet a praktizáló családorvosok számának folyamatos csökkenése hazánkban, akiknak elsődleges szerepük van a cukorbetegek normoglykaemiás állapotának elérésében és fenntartásában [26]. Azonban az RD vonatkozásában tapasztalt regionális eltérés valószínúleg multifaktoriális eredetű (kiszürt és kezelt cukorbetegek száma, kezelési és gondozási szokások, szemészeti szürés lefedettsége, szemészeti ellátás, valamint genetikai és egyéb tényezők). Ezenkívül eredményeinkre valószínúleg befolyással van az is, hogy Közép-Magyarországon többen utasították vissza a szemfenékvizsgálatot, mint az ország egyéb részein.

A nemzeti irányelvek szerint minden cukorbetegnek, szemészeti szövődmény meglététől függetlenül, legalább évente egyszer javasolt pupillatágításban végzett szemfenékvizsgálat elvégeztetése. Ezzel szemben országos felmérési adataink szerint a cukorbetegeknek csak $45,7 \%$-a volt egy éven belül, illetve $27,4 \%$-uk még sohasem volt szemfenékvizsgálaton [11]. Regionális adatainkból látható, hogy a közép-magyarországi cukorbeteg páciensek nagyobb arányban vettek részt egy éven belüli szemészeti vizsgálaton az ország egyéb részeihez képest, illetve Közép-Magyarországon találtuk a legkevesebb olyan cukorbeteg résztvevőt, aki még sohasem vett részt szemfenékvizsgálaton. A cukorbetegség okozta súlyos szemészeti szövődmények megfelelő gyakoriságú kontrollvizsgálatok segítségével megelőzhetőek és kezelhetőek lennének [27]. A szemészeti ellátáshoz való egyenló hozzáférés szükséges lenne a cukorbetegség és annak szemészeti szövődményeinek következtében kialakuló vakság gyakoriságának csökkentéséhez. Ehhez költséghatékonysági szempontból országos, telemedicinális szemfenéki szürővizsgálat bevezetése és végzése volna a legcélravezetóbb megoldás [28].

Tanulmányunk korlátai közé tartozik az egy alkalommal végzett vércukormérés, illetve az 50 év alatti személyek kizárása. A legjelentősebb korlátja azonban, hogy Közép-Magyarországon többen utasították vissza a pupillatágításos vizsgálatot, mint az ország egyéb részein (26,5\% vs. $20,7 \%$ és 15,7\%, Közép-, Nyugat-, illetve Ke-
let-Magyarországon). Tanulmányunk erősségei közé tartozik az egész országra vonatkozó lefedettség, valamint a reprezentatív és nagy mintaszám.

\section{Következtetések}

Elmondhatjuk, hogy a cukorbetegség prevalenciája Kelet-Magyarországon, az RD előfordulási gyakorisága pedig Nyugat-Magyarországon a legmagasabb hazánkban. A nemzeti irányelvek által elóírt, legalább évenkénti szemfenékvizsgálaton legtöbben Közép-Magyarországon vettek részt, ami feltehetőleg összefüggésben van a szemészeti vizsgálat jobb elérhetőségével. Eredményeink alapján fontos lenne a szemészeti alapellátás - föleg vidéki településeken való - megerősítése, vagy nemzeti szemészeti telemedicinális szúrőprogram indítása. A szemészeti telemedicinális szűrőprogram előnye a költséghatékonysággal és alacsonyabb humán erőforrás igényével magyarázható.

Anyagi támogatás: A vizsgálatot a Lions Clubs International Foundation (Oak Brook [IL], Amerikai Egyesült Államok] támogatta (G. Sz.: SF 1825/UND). A támogató szervezetnek nem volt szerepe a tanulmány megtervezésében vagy elvégzésében.

Szerzői munkamegosztás: T. G.: A vizsgálat megtervezése, lefolytatása és a kézirat megírása. Sz. D.: A vizsgálat megtervezése és az adatok feldolgozása. S. G. L., Pé. A., Sz. I., L. R., T. G. Zs.: A vizsgálat lefolytatása és az adatok feldolgozása. Pa. A., N. Z. Zs.: A kézirat megszövegezése. H. L., N. J.: A vizsgálat megtervezése, vezetése és a kézirat megszövegezése. A cikk végleges változatát valamennyi szerző elolvasta és jóváhagyta.

Érdekeltségek: A szerzőknek nincsenek érdekeltségeik.

\section{Irodalom}

[1] International Diabetes Federation: IDF Diabetes Atlas, 7th edn. International Diabetes Federation, Brussels, Belgium, 2015. Available from: http://www.diabetesatlas.org [accessed: November 23, 2016].

[2] Yau, J. W., Rogers, S. L., Kawasaki, R., et al.: Global prevalence and major risk factors of diabetic retinopathy. Diabetes Care, 2012, 35(3), 556-564.

[3] Resnikoff, S., Pascolini, D., Mariotti, S. P., et al.: Global magnitude of visual impairment caused by uncorrected refractive errors in 2004. Bull. World Health Organ., 2008, 86(1), 63-70.

[4] Pascolini, D., Mariotti, S. P.: Global estimates of visual impairment: 2010. Br. J. Ophthalmol., 2012, 96(5), 614-618.

[5] Hogan, P., Dall, T., Nikolov, P.: Economic costs of diabetes in the US in 2002. Diabetes Care, 2003, 26(3), 917-932.

[6] Pararajasegaram, R.: VISION 2020 - the Right to Sight: from strategies to action. Am. J. Ophthalmol., 1999, 128(3), 359360 . 
[7] Gupta, N., Kocur, I.: Chronic eye disease and the WHO Universal Eye Health Global Action Plan 2014-2019. Can. J. Ophthalmol., 2014, 49(5), 403-405.

[8] Polack, S., Yorston, D., López-Ramos, A., et al.: Rapid assessment of avoidable blindness and diabetic retinopathy in Chiapas, Mexico. Ophthalmology, 2012, 119(5), 1033-1040.

[9] Minderhoud, J., Pawiroredjo, J. C., Bueno de Mesquita-Voigt, A M., et al.: Diabetes and diabetic retinopathy in people aged 50 years and older in the Republic of Suriname. Br. J. Ophthalmol., 2015, 100(6), 814-818.

[10] Zatic, T., Bendelic, E., Paduca, A., et al.: Rapid assessment of avoidable blindness and diabetic retinopathy in Republic of $\mathrm{Mol}-$ dova. Br. J. Ophthalmol., 2015, 99(6), 832-836.

[11] Tóth, G., Szabó, D., Sándor, G. L., et al.: Diabetes and diabetic retinopathy in people aged 50 years and older in Hungary. Br. J. Ophthalmol., 2016 Oct 28. doi: 10.1136/bjophthalmol-2016309016. [Epub ahead of print]

[12] Domján, B. A., Ferencz, V., Tänczer, T., et al.: Large increase in the prevalence of self-reported diabetes based on a nationally representative survey in Hungary. Prim. Care Diabetes, 2016 Sep 23. pii: S1751-9918(16)30097-3. doi: 10.1016/j. pcd.2016.09.001. [Epub ahead of print]

[13] Kuper, H., Polack, S., Limburg, H.: Rapid assessment of avoidable blindness. Community Eye Health, 2006, 19(60), 68-69.

[14] Ruta, L. M., Magliano, D. J., Lemesurier, R., et al.: Prevalence of diabetic retinopathy in type 2 diabetes in developing and developed countries. Diabet. Med., 2013, 30(4), 387-398.

[15] Mokán, M., Galajda, P., Prídavkova, D., et al.: Prevalence of diabetes mellitus and metabolic syndrome in Slovakia. Diabetes Res. Clin. Pract., 2008, 81(2), 238-242.

[16] Metelko, Z., Pavlić-Renar, I., Poljicanin, T., et al.: Prevalence of diabetes mellitus in Croatia. Diabetes Res. Clin. Pract., 2008, 81(2), 263-267.

[17] Vamos, E. P., Kopp, M. S., Keszei, A., et al.: Prevalence of diabetes in a large, nationally representative population sample in Hungary. Diabetes Res. Clin. Pract., 2008, 81(3), e5-e8.

[18] Jermendy, G., Nádas, J., Szigethy, E., et al.: Prevalence rate of diabetes mellitus and impaired fasting glycemia in Hungary: crosssectional study on nationally representative sample of people aged 20-69 years. Croat. Med. J., 2010, 51(2), 151-156.

[19] Green, A., Sortsø, C., Jensen, P. B., et al.: Incidence, morbidity, mortality, and prevalence of diabetes in Denmark, 2000-2011: results from the Diabetes Impact Study 2013. Clin. Epidemiol., $2015,7,421-430$.
[20] O'Connor, A., Wellenius, G.: Rural-urban disparities in the preva lence of diabetes and coronary heart disease. Public Health, $2012,126(10), 813-820$.

[21] Harsányi, E., Harsányi, E., Nagy, A. J.: Disparities in regional development in Hungary and in Northern Great Plain Region. [Területi fejlettségi különbségek Magyarországon és az ÉszakAlföldi Régióban.] Agrártudományi Közlemények, 2005, 18, 62-71. [Hungarian]

[22] Bálint, L., Gödri, I.: Internal migration. In: Monostori, J., Őri, P., Spéder, Z. (eds.): Demographic potrait of Hungary. [Belföldi vándorlás. In: Monostori, J., Öri, P., Spéder, Zs. (szerk.): Demográfiai portré.] Központi Statisztikai Hivatal, Népességtudományi Kutatóintézet, Budapest, 2015, 171-186. [Hungarian]

[23] Hungarian Central Statistical Office: Regional differences in economic trends, 2013. [Köztársasági Statisztikai Hivatal: A gazdasági folyamatok regionális különbségei, 2013.] Központi Statisztikai Hivatal, Budapest, 2013, 1-45. [Hungarian]

[24] Nadeau, D. A.: Management of type 2 diabetes mellitus in selfmotivated patients: optimized diet, exercise, and medication for weight loss and cardiometabolic fitness. Phys. Sportsmed., 2014, $42(4), 49-59$.

[25] Hungarian Central Statistical Office: Life expectancy at birth, average age (2001-). [Központi Statisztikai Hivatal: Születéskor várható átlagos élettartam, átlagéletkor (2001-).] Központi Statisztikai Hivatal, 2016. Available from: http://www.ksh.hu/ docs/hun/xstadat/xstadat_eves/i_ wdsd008.html [accessed: November 23, 2016]. [Hungarian]

[26] Hungarian Central Statistical Office: General practitioners and pediatricians, December 31 (2000-). [Központi Statisztikai Hivatal: Háziorvosok és házi gyermekorvosok, december 31 . (2000-).] Központi Statisztikai Hivatal, 2016. Available from: http://www.ksh.hu/docs/hun/xstadat/xstadat_eves/i_ fea002.html [accessed: January 2, 2017]. [Hungarian]

[27] Bunce, C., Wormald, R.: Leading causes of certification for blindness and partial sight in England \& Wales. BMC Public Health, $2006,6,58$.

[28] Szabo, D., Fiedler, O., Somogyi, A., et al.: Telemedical diabetic retinopathy screening in Hungary: a pilot programme. J. Telemed. Telecare, 2015, 21(3), 167-173.

(Tóth Gábor dr., Budapest, Üllői út 26., 1085 e-mail: gabortothgabor@gmail.com)

\section{A rendezvények és kongresszusok híranyagának leadása}

a lap megjelenése előtt legalább 40 nappal lehetséges, a 6 hetes nyomdai átfutás miatt. Kérjük megrendelőink szíves megértését.

A híranyagokat a következő címre kérjük:

Orvosi Hetilap titkársága: edit.budai@akademiai.hu Akadémiai Kiadó Zrt. 